\title{
Translating a gene expression signature for multiple myeloma prognosis into a robust high-throughput assay for clinical use
}

Ryan van Laar ${ }^{1 *}$, Rachel Flinchum', Nathan Brown', Joseph Ramsey', Sam Riccitelli', Christoph Heuck², Bart Barlogie $^{2}$ and John D Shaughnessy $\mathrm{Jr}^{1}$

\begin{abstract}
Background: Widespread adoption of genomic technologies in the management of heterogeneous indications, including Multiple Myeloma, has been hindered by concern over variation between published gene expression signatures, difficulty in physician interpretation and the challenge of obtaining sufficient genetic material from limited patient specimens.

Methods: Since 2006, the 70-gene prognostic signature, developed by the University of Arkansas for Medical Sciences (UAMS) has been applied to over 4,700 patients in studies performed in 4 countries and described in 17 peer-reviewed publications. Analysis of control sample and quality control data compiled over a 12-month period was performed.

Results: Over a 12 month period, the 70-gene prognosis score (range 0-100) of our multiple myeloma cell-line control sample had a standard deviation of 2.72 and a coefficient of variance of 0.03 . The whole-genome microarray profile used to calculate a patient's GEP70 score can be generated with as little as $15 \mathrm{ng}$ of total RNA; approximately 30,000 CD-138+ plasma cells. Results from each GEP70 analysis are presented as either low (70-gene score <45.2) or high ( $\geq 45.2$ ) risk for relapse (newly diagnosed setting) or shorter overall survival (relapse setting). A personalized and outcome-annotated gene expression heat map is provided to assist in the clinical interpretation of the result.

Conclusions: The 70-gene assay, commercialized under the name 'MyPRS ${ }^{\oplus \prime}$ (Myeloma Prognostic Risk Score) and performed in Signal Genetics' CLIA-certified high throughput flow-cytometry and molecular profiling laboratory is a reproducible and standardized method of multiple myeloma prognostication.
\end{abstract}

\section{Background}

By coupling immunomagnetic and fluorescence-based cell separation with microarray gene expression profiling, researchers have dramatically improved the understanding of how hematological malignancies, including Multiple Myeloma (MM), develop, progress, and respond to therapy. Multiple Myeloma accounts for $1 \%$ of all cancers, affecting an estimated 22,350 people in the US in 2013 and resulting in 10,710 deaths (cancer.gov). Gene expression signatures, generated using tissue obtained at the time of diagnosis, have been demonstrated to accurately predict

\footnotetext{
* Correspondence: rvanlaar@signalgenetics.com

'Signal Genetics, 667 Madison Avenue, 14th Floor, New York, NY 10065, USA Full list of author information is available at the end of the article
}

patient outcome and stratify patients into clinically relevant molecular subgroups in many types of cancers [1-5].

By performing large multidisciplinary studies of multiple myeloma, researchers at University of Arkansas for Medical Sciences (UAMS) developed a 70-gene signature of aggressive disease (GEP70), corresponding to increased risk of relapse and poorer overall survival probability [6]. This signature was independently validated in separate patient populations for its ability to predict risk of relapse and shorter overall survival in newly diagnosed multiple myeloma and proved superior to other prognostic risk scores in multivariate analyses. In the post-relapse setting, GEP70 is able to stratify patients into groups with highly significant differences

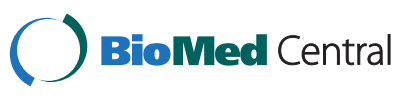

(c) 2014 van Laar et al.; licensee BioMed Central Ltd. This is an Open Access article distributed under the terms of the Creative Commons Attribution License (http://creativecommons.org/licenses/by/4.0), which permits unrestricted use, distribution, and reproduction in any medium, provided the original work is properly credited. The Creative Commons Public Domain Dedication waiver (http://creativecommons.org/publicdomain/zero/1.0/) applies to the data made available in this article, unless otherwise stated. 
in overall survival [7]. Since 2006, the UAMS GEP70 assay has been validated on patient cohorts totaling over 4,700 patients, described in the 17 publications listed in Table 1. These validation studies, performed independently by German, French, Italian, British, Dutch, and US-based clinical research groups, have repeatedly shown that the prognostic significance the 70-gene algorithm is superior to both conventional risk stratification methods and other gene expression signatures in multivariate analyses. Patients identified as high risk by GEP70 (ranging from 15-30\% of all patients, depending on the characteristics of the patient population profiled) may benefit from alternative treatment regimens and/or referral to an appropriate clinical trial. Importantly, the vast majority of cases, defined as low risk, might benefit from reduced intensity treatments.

In order to translate any gene expression signature from the research setting to routine use in a clinical laboratory, a number of logistical and technical challenges must be overcome. These include defining the minimum amount of patient specimen (e.g. bone marrow aspirate) required to isolate sufficient plasma cell RNA for expression profiling and establishing a comprehensive quality control framework in order to monitor laboratory performance over time and ensure reliability of results. Yet another challenge is how best to present the gene expression algorithm results in order to enable straightforward interpretation by treating physicians and incorporation into patient management regimens.

In this paper we describe the use of a high-throughput process, combining cell isolation, flow cytometry and gene expression profiling to provide physicians with personalized prognostic assessments of multiple myeloma, using bone marrow aspirate, based on the comprehensively validated GEP70 signature. Data are presented to describe the stability of the assay over time as performed in a CLIAcertified clinical laboratory diagnostic setting.

\section{Methods}

\section{Plasma cell quantification and separation}

Processing of bone marrow aspirate specimens submitted for $\mathrm{MyPRS}^{\circ}$ analysis occurs largely as previously described [23]. CD138+ plasma cell isolation from red blood cell lysed bone marrow aspirates is performed by immunomagnetic bead selection with monoclonal mouse antihuman CD138 antibodies using the AutoMACS Pro automated separation system (Miltenyi-Biotec, Auburn, CA). Minimum PC purity of $\geq 80 \%$ homogeneity is confirmed by 2-color flow cytometry using CD38+/CD45- post-sort (after immunomagnetic bead selection) criteria (Becton Dickinson, San Jose, CA).

Determination of CD138+ cell presence is performed on the initial whole bone marrow aspirate by removing an aliquot from the gently homogenized bone marrow aspirate that was mixed with EDTA at the time of collection.
This aliquot is incubated with CD138 PE and CD45 FITC antibodies (Miltenyi, CA), and then the red blood cells are lysed. The remaining cells are washed with phosphate buffered saline (PBS) and flow cytometry is performed. The pre-sort cell percentage (prior to immunomagnetic bead selection) is determined by identifying the CD138+/CD45cells from the total population after red blood cell (RBC) lysis. This determination is performed on either the FACS Calibur system or the FACS Aria III system (Becton Dickinson, NJ). Once the presence of CD138+ cells has been confirmed, the bone marrow aspirate undergoes RBC-lysis and is washed with autoMACS Running Buffer (Miltenyi, CA).

Cell count is determined using the Nucleocounter NC-100 (Chemometec, Denmark) according to manufacturer recommendations. Immunomagnetic beads are then bound to the cells and the remaining unbound beads are removed through a second Running Buffer wash. The CD138+ cells are isolated from the remaining cells using the AutoMACS Pro Separator (Miltenyi, CA) according to manufacturer recommendations. If $80 \%$ cell homogeneity is not obtained, the specimen either undergoes a second immunomagnetic isolation and/or enriched using CD38 PE and CD45 FITC antibodies on the FACS Aria III (Becton Dickinson, NJ).

In keeping with institutional, federal, and Helsinki Declaration guidelines, all identifiable patients gave written informed consent for undergoing bone marrow sampling for gene expression profiling and the institutional review board of the University of Arkansas for Medical Sciences approved the research studies. Consent was not obtained from patients where data were analyzed anonymously and not associated with any identifiable or longitudinal information.

\section{RNA isolation and microarray analysis}

Cell lysis and total-RNA isolation from purified CD138+ plasma cells is performed using the RNeasy Micro Kit (Qiagen, Germany). RNA concentration and purity is determined using a Nanodrop Spectrophotometer (Thermo Scientific, Wilmington) and the integrity is assessed using the Agilent Bioanalyzer 2100 system (CA). Doublestranded complementary DNA (cDNA) and amplified biotinylated antisense RNA (aRNA or cRNA) are synthesized from total RNA using the Affymetrix 3' IVT Express Kit. The aRNA is fragmented and hybridized to wholegenome U133 Plus 2.0 GeneChip microarrays (Affymetrix, Santa Clara, CA), according to manufacturer recommendations. Hybridized GeneChips are scanned with the Affymetrix GeneChip Scanner 3000DX V2, an FDA-cleared, CE-IVD marked system. Scanned GeneChip files (CEL files) are normalized and assessed for hybridization success and sample quality by a proprietary gene expression data quality control system (ResultsPX $\mathrm{X}^{\mathrm{m}}$ ), previously described [2]. 
Table 1 Peer-reviewed publications describing the use of GEP70/MyPRS ${ }^{\oplus}$ gene expression profiling on patients with multiple myeloma

\section{Date}

1-Jan-2006

25-May-2006

14-Nov-2006

9-May-2007

22-Jun-2007

7-Sep-2007

1-Dec-2007

15-Jan-2008

30-Jun-2008

29-Mar-2009

25-Jun-2009

14-Mar-2010 Patient series

Newly diagnosed patients with MM treated with 2 cycles of high-dose melphalan and autologous stem cell transplantation [8].

Publication

Newly diagnosed patients treated with high-dose melphalan-based tandem transplants [9].

Newly diagnosed patients with multiple myeloma (MM) treated on 2 separate protocols [6].

Newly diagnosed patients treated with $\Pi 2[10]$

Newly diagnosed patients with myeloma treated with Total therapy 3 (incorporating bortezomib into a melphalan-based tandem transplant regimen) [11]

Newly diagnosed multiple myeloma patients treated with high-dose melphalan and stem cell transplant [12]

Newly diagnosed patients with myeloma received a tandem autotransplant regimen [13].

Relapsed myeloma patients enrolled in the APEX phase 3 clinical trial that compared single-agent bortezomib (B) to high-dose dexamethasone (HD) [14]

Two hundred fifty patients with myeloma at diagnosis with at least 500,000 available bone marrow CD138+ plasma cells [15]

Untreated myeloma patients with cytogenetic abnormalities (CA) present in randomly sampled (RS) or focal lesion (FL) bone marrow sites [16]

Myeloma patients previously enrolled in tandem transplantation trial Total Therapy 2 [7].

Newly diagnosed patients with multiple myeloma entered into the MRC Myeloma IX study [17].

Shaughnessy JD Jr, Barlogie B. "Using genomics to identify high-risk Myeloma after autologous stem cell transplantation Biol Blood Marrow Transplant 2006; 12 (1 Suppl 1):77-80.

Zhan et al. "The molecular classification of multiple myeloma". Blood 2006; 108(6):2020-2028.

Shaughnessy et al. "A validated gene expression model of high-risk multiple myeloma is defined by deregulated expression of genes mapping to chromosome 1 ". Blood 2007; 109:2276-84

Shaughnessy et al. "Testing standard and genetic parameters in 220 patients with multiple Myeloma with complete data sets: superiority of molecular genetics". Br J Haematol 2007 137:530-536.

Barlogie et al. "Incorporating bortezomib into upfront

treatment for multiple myeloma: early results of total therapy 3". Br J Haemotol 2007; 138:176-185

Chng et al. "Translocation t(4;14) retains prognostic significance even in the setting of high-risk molecular signature". Leukemia 2008; 22:459-61.

Haessler et al. "Benefit of complete response in multiple myeloma limited to high-risk subgroup identified by gene expression profiling". Clin Cancer Res. 2007; 13(23):7073-7079

Zhan et al. "High-risk myeloma: a gene expression based risk-stratification model for newly diagnosed multiple myeloma treated with high-dose therapy is predictive of outcome in relapsed disease treated with single-agent bortezomib or high-dose dexamethasone." Blood 2008; 111 (2):968-969.

Decaux etl al. Prediction of Survival in Multiple Myeloma Based on Gene Expression Profiles Reveals Cell Cycle and Chromosomal Instability Signatures in High-Risk Patients and Hyperdiploid Signatures in Low-Risk Patients: A Study of the Intergroupe Francophone du Myélome JCO October 10, 2008:4798-4805;

Zhou et al. "Cytogenetic abnormalities in multiple myeloma: poor prognosis is linked to concomitant detection in random and focal lesion bone marrow samples and associated with high-risk gene expression profile". Br J Haematol 2009; 145(5):637-641

Nair et al. "Gene expression profiling of plasma cells at myeloma relapse from tandem transplantation trial Total Therapy 2 predicts subsequent survival". Blood 2009; 113:6572-5.

Dickens et al. Homozygous Deletion Mapping in Myeloma Samples Identifies Genes and an Expression Signature Relevant to Pathogenesis and Outcome. Clin Cancer Res March 15, 2010 16:1856-186 
Table 1 Peer-reviewed publications describing the use of GEP70/MyPRS ${ }^{\oplus}$ gene expression profiling on patients with multiple myeloma (Continued)

\begin{tabular}{|c|c|c|c|}
\hline 12-Apr-2010 & 52 & Patients newly diagnosed with MM [18]. & $\begin{array}{l}\text { Zhou et al. "High-risk myeloma is associated with global } \\
\text { elevation of MiRNAs and overexpression of EIF2C2/AGO2". } \\
\text { Proc Natl Acad Sci USA 2010; 107(17): 7904-790 }\end{array}$ \\
\hline 30-Sep-2010 & 757 & $\begin{array}{l}\text { Previously untreated patients undergoing high-dose } \\
\text { chemotherapy [19]. }\end{array}$ & $\begin{array}{l}\text { Hose et al. "Proliferation is a central independent prognostic } \\
\text { factor and target for personalized and risk adapted treatment } \\
\text { in multiple myeloma". Haematologica 2011; 96(1):87-95. }\end{array}$ \\
\hline 20-Aug-2010 & 275 & $\begin{array}{l}\text { Newly diagnosed patients with symptomatic or } \\
\text { progressive myeloma [20]. }\end{array}$ & $\begin{array}{l}\text { van Rhee et al. Total Therapy } 3 \text { for multiple myeloma: prognostic } \\
\text { implications of cumulative dosing and premature discontinuation } \\
\text { of VTD maintenance components, bortezomib, thalidomide, and } \\
\text { dexamethasone, relevant to all phases of therapy. Blood } 2010 \\
\text { 116:1220-1227; }\end{array}$ \\
\hline 7-Oct-2010 & 320 & $\begin{array}{l}\text { Newly diagnosed patients with MM (Dutch-Belgian } \\
\text { Cooperative Trial Group for Hemato-Oncology [21]. }\end{array}$ & $\begin{array}{l}\text { Broyl et al. Gene expression profiling for molecular classification } \\
\text { of multiple myeloma in newly diagnosed patients. Blood } 2010 \\
116: 2543-2553 ;\end{array}$ \\
\hline 22-Aug-2011 & 45 & $\begin{array}{l}\text { Patients with myeloma receiving initial therapy with } \\
\text { lenalidomide and dexamethasone [22]. }\end{array}$ & $\begin{array}{l}\text { Kumar et al. "Impact of gene expression profiling-based risk } \\
\text { stratification in patients with myeloma receiving initial therapy } \\
\text { with lenalidomide and dexamethasone". Blood 2011; } \\
\text { 118(16): 4359-4362. }\end{array}$ \\
\hline
\end{tabular}

Publications listed are the first use of GEP70 to stratify patients in the relevant cohort as high or low risk for. Additional publications reanalyzing the same (or subsets of a) patient series are not shown. 
GEP70 risk scores are calculated using the method originally described by Shaughnessy et al. [6], with the additional modification of scaling the score to a range of 0 to 100 to assist in interpretation. This scaling is done using the equation [original GEP70 + 1.6] * $20=$ scaled GEP70.

\section{Control sample analysis}

Positive and negative control specimens are analyzed alongside all clinical $\mathrm{MyPRS}^{\circ}$ samples. Positive controlsample analysis is performed using the multiple myeloma cell line $\mathrm{H} 929$ which is grown as recommended (American Type Culture Collection, Chantilly, VA). To prepare the cell line for repeated control sample use, cells are consolidated and analyzed for homogeneity and for $\mathrm{CD} 138+$ presence. Once $+80 \% \mathrm{CD} 138+$ homogeneity is confirmed, the cells are pelleted, placed on RLT (plus 2 -mercaptoethanol) buffer and frozen at $-80^{\circ} \mathrm{C}$. Each aliquot of H929 cells is tested over several months to generate sufficient data in order to calculate the standard deviation of its GEP70 risk score. A Levy Jennings plot is used to analyze the positive control specimen processed in parallel to each batch of clinical specimens, with results outside of the median +/-3SD range being rejected.

Negative control analysis is performed using aliquots of RLT (+2-mercaptoethanol) buffer and frozen. The negative control is inserted into a batch of samples at RNA isolation and is carried all the way through aRNA amplification. Detection of aRNA in the negative control specimen prior to microarray hybridization results is a sign of contamination and cause for rejection.

\section{Replication of GEP70 signature between UAMS and Signal Genetics laboratories}

To evaluate the difference between GEP70 risk scores generated in the original research laboratory (UAMS) and the clinical laboratory (Signal Genetics LLC, AR) a series of 99 bone marrow aspirates were analyzed. Specimen preparation, microarray hybridization and data analysis methods were performed as described above. GEP70 scores were compared by performing intra-class correlation, Passing and Bablok regression and chisquare analysis of high/low risk group classification in MedCalc 12.7.8 (MedCalc Software bvba, Belgium) [24].

\section{Interpretation of GEP70 score using personalized gene expression heat maps}

The GEP70 risk score for each MyPRS analysis performed was visualized by creation of a personalized twodimensional heat map generated by the ResultsPX ${ }^{\mathrm{mm}}$ genomic data management platform developed by Signal Genetics. This system uses Microsoft SQL Server (Redmond, WA) databases, $\mathrm{R}$ [25] and Bioconductor [26] and custom scripts to display the expression profile of the prognostic GEP70 gene score within the context of the 559 multiple myeloma patients from two previously published datasets, including data from patients used to develop the algorithm [6]. The 5-year relapse status of each patient is shown at the top of each gene profile (red: relapse, blue: no relapse) along with the corresponding risk score.

To generate a personalized gene expression data heat map for each patient analyzed, the following steps are performed by Signal Genetics ResultsPX ${ }^{\mathrm{Tw}}$ analysis software:

i. Load the matrix of the MAS5 normalized gene expression data for the 70 genes by 559 patients.

ii. Attach the 70 gene data from the patient being analyzed to the matrix, making it 70 genes by 560 patients.

iii. Order 560 columns of the matrix $(1$ column $=1$ patient) left-to-right by increasing GEP70 score.

iv. Order the 70 rows of the matrix ( 1 row $=1$ gene $)$ using hierarchical clustering, as implemented by 'hclust' R library (http://stat.ethz.ch/R-manual/Rpatched/library/stats/html/hclust.html).

No 'batch effect' modification is performed during this procedure as the 70 gene $\mathrm{x} 559$ patient dataset was that used to originally develop the GEP70 algorithm. These data were produced by the UAMS MIRT laboratory and were used in the validation studies performed herein to ensure the 70-gene assay produces statistically equivalent results when performed in the Signal Genetics clinical laboratory.

\section{Results}

Genomic profiling of paired aliquots of patient CD138+ cells in research and clinical laboratories shows high correlation of GEP70 scores

Ninety-nine patient bone marrow aspirate specimens were split into two aliquots and processed as described in both the UAMS research laboratory and at Signal Genetics' CLIA-certified laboratory (Figure 1). The intraclass correlation coefficient for the set of 99 GEP70 scores generated by UAMS and Signal Genetics is 0.98 (95\% CI: 0.97 to 0.99 ), indicating a high level of consistency. The Cusum test for linearity revealed no significant deviation from linearity $(P=0.17)$ [24].

In order to assess the clinical implications of the small difference in risk scores observed between the two laboratories, ROC analysis was performed using 5-year relapse-free survival as the binary outcome metric. The AUC of the UAMS risk score was 0.67 (95\% CI 0.57 to 0.76) compared to the Signal Genetics AUC of 0.66 (95\% CI: 0.56 to 0.75 ), a statistically insignificant difference $(P=0.402)$. This indicates that no significant difference exists in the association of the GEP70 score with multiple 


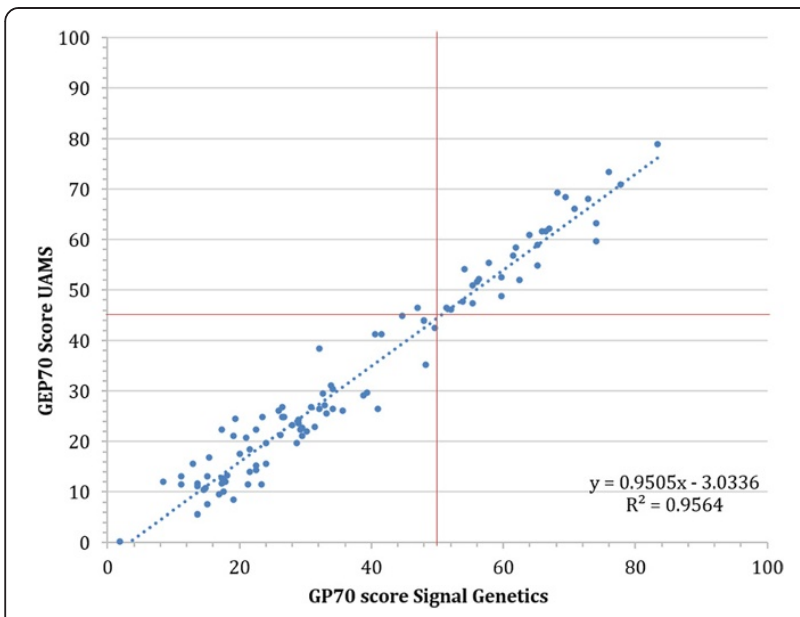

Figure 1 Inter-laboratory reproduciblity; Analysis of GEP70 scores calculated on 99 clinical bone marrow aspirate specimens analyzed in parallel by UAMS Myeloma Instiute for Research and Treatment (MIRT) (1a. y-axis) and Signal Genetics CLIA laboratory (1b x-axis). Lines at 45.2 correspond to the low/ high risk threshold.

myeloma relapse risk based on the processing of a specimen in the research or clinical laboratory setting.

Analysis of control specimen GEP70 risk score shows high level of consistency in MyPRS ${ }^{\circledR}$ analyses over time

Along with each batch of clinical bone marrow aspirate samples analyzed, an aliquot of RNA from a multiple myeloma cell-line (H929) is analyzed and its GEP70 score is assessed for stability. Over a twelve-month period from August 2012 to August 2013, 102 control sample analyses were performed. As shown in Figure 2, the median value of the GEP70 score over time was 91.2, with a standard deviation of 2.7 and 3.0\% coefficient of variance.

Next we sought to evaluate the reproducibility of the GEP70 scores across the dynamic range of the assay (i.e. low risk 0 to 45.2 , high risk 45.2 to 100). Thirty specimens of MM RNA were analyzed in duplicate, approximately one month apart (Figure 3). A high degree of correlation was observed between the repeated measurements $\left(r^{2}=0.99\right)$ with no statistically significant deviation from linearity detected by the Cusum test $(\mathrm{P}=$ 0.98).

Variation in clinical bone marrow aspirate specimen plasma cell content has negligible impact on RNA isolation and gene expression profile quality

Bone marrow aspirate specimens of varying absolute and relative CD138+ plasma cell content are submitted for GEP70 analysis from treatment centers throughout the United States. Immunomagnetic and fluorescence based isolation of CD138+ plasma cells is routinely

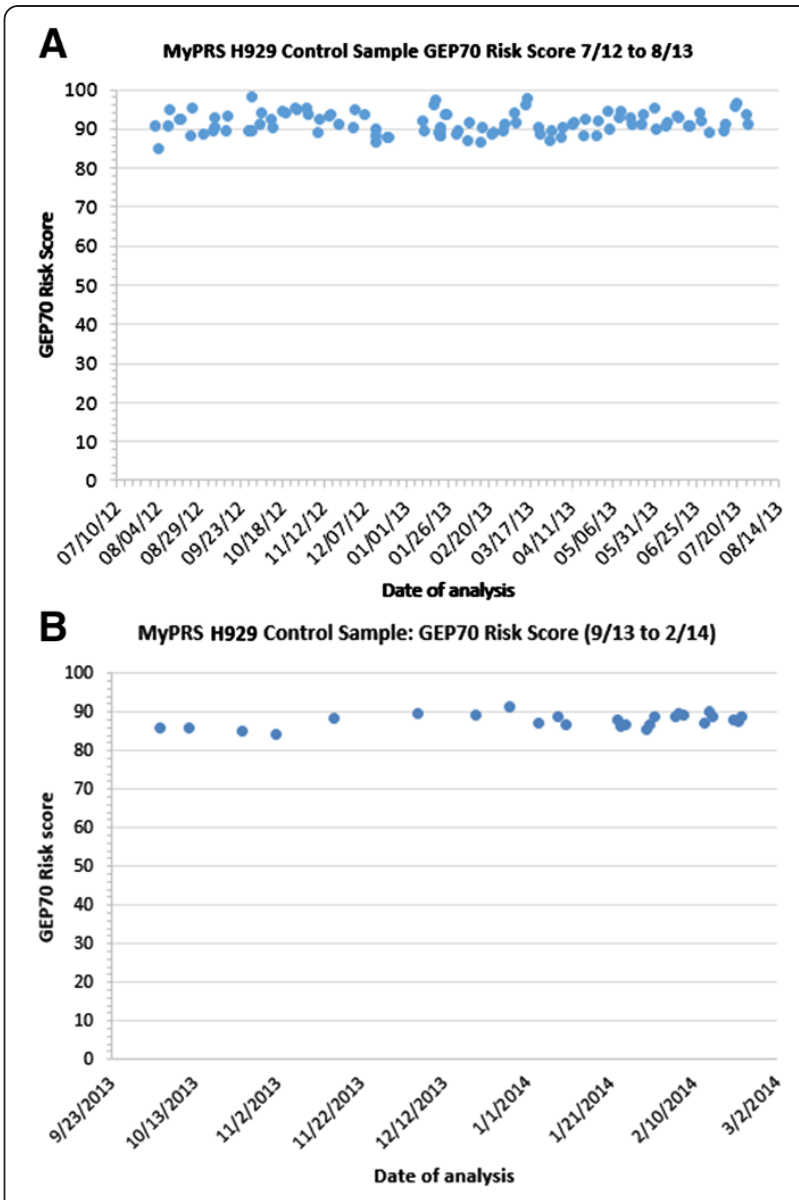

Figure 2 Analysis of MyPRS Control Sample stability over time. MyPRS Control Sample stability over time; (A) H929 Control sample GEP70 scores generated bewteen August 2012 and August 2013 exhitit high stability over time. No gradual shift up or down in risk score is observed. Standard deviation of risk scores in this analysies was 2.72 and a CV of 0.03. (B) Control sample data from September 2013 to February 2014 (new aliquot of H929) shows further improvements in assay stability. Standard deviation 1.70, CV 0.019 .

performed using methods described on every specimen to isolate, and if necessary enrich, the target plasma cells in the specimen.

We investigated the association between the relative malignant cell content, RNA integrity and the resulting GEP70 risk scores by performing a retrospective analysis of data generated from routine bone marrow aspirate specimens submitted to Signal Genetics over a period of twelve months. Agilent Bioanalzyer RNA integrity number (RIN; range $0-10$ ) and the GEP70 risk score (range 0-100) data were compiled from 1000 randomly selected specimens submitted to Signal Genetics for routine GEP70 analysis between August 2012 and July 2013.

Within this series of 1000 specimens, the CD138+ cell content ranged from the lower acceptance threshold of $0.25 \%$ to $96.2 \%$ (mean: $12.80 \%$, median: $4.63 \%$ ). Despite this wide range of cellularity, skewed toward the lower 


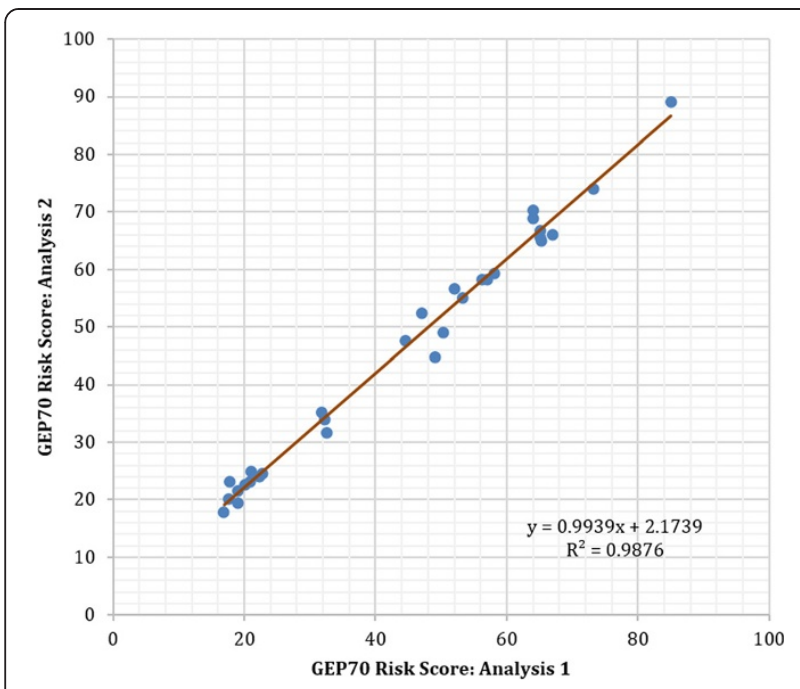

Figure 3 Intra-laboratory reproducibility; Comparison of GEP70 scores from 30 specimens analyzed in duplicate. Correlation coefficient of 0.98 shows an extremely high degree of reproducibility between experiments.

end of the spectrum, Figure $4 \mathrm{a}$ and $\mathrm{b}$ show that only a weak correlation exists between the RNA integrity number, GEP70 score and pre-sorted specimen percentage of CD138+ cells $\left(r^{2}=0.13\right.$ and 0.010 , respectively). After cell sorting, specimens with less than $80 \%$ purity are excluded from further analysis in order to ensure the genomic profile represents the cells of interest rather than other potentially contaminating material. Inspection of specimens with cell content between 80 and $100 \%$ revealed there is no significant association between the relative CD138+ plasma cell content and RNA integrity, or the GEP70 risk score, $r^{2}=0.017$ and $r^{2}=<0.001$, respectively (Figure $4 \mathrm{c}-\mathrm{d}$ ).

These data show that the specimen preparation methods used to isolate the malignant cells from a patient's bone marrow aspirate are robust and not impacted by natural variations in specimen quality and relative quantity of malignant plasma cells. This ensures the GEP70 prognostic risk score is an accurate and reproducible prediction of patient prognosis, with negligible impact from biological or other sources of specimen variation.

\section{Determining the minimum amount of CD138+ plasma cell RNA required for reliable gene expression profiling}

As stated, patient bone marrow aspirate specimens vary in terms of plasma cell number, viability and purity. To determine minimum number of viable $\mathrm{CD} 138+$ plasma cells necessary to generate a high quality GEP and reproducible GEP70 score, we performed two titration studies in which varying amounts of pooled MM aRNA were hybridized to Affymetrix microarrays in triplicate.
By hybridizing varying amounts of pooled aRNA (range: $10 \mu \mathrm{g}$ to $2 \mu \mathrm{g}$ ) to multiple GeneChip we were able to extrapolate to a minimum number of CD138+ plasma cells required to accept a specimen for routine GEP70 analysis. GeneChip quality control metrics and GEP70 risk scores were used to assess the impact of the using lower amounts of aRNA compared to the amounts protocols used in previous studies $[6,7,9]$. After repeating the experiment twice, it was apparent that there was negligible variation in the GEP70 score, even using as little as 2 ug of pooled aRNA, as shown in Table 2. The variance of the GEP70 score in titration experiment 1 was $1.5 \%$ and in experiment 2 was $2.8 \%$.

These data also showed no significant changes in GEP data quality metrics across the range assessed. All hybridizations successfully passed the automated series quality control metrics developed by Signal Genetics, which are comprised of chip and data assessments (with associated pass/warning/fail thresholds) that have been established by analyzing large databases GeneChip quality data generated using aRNA concentrations at or above those recommended by the manufacturer [2].

Next we tested individual fresh or archival MM bone marrow aspirate samples submitted for MyPRS analysis with RNA yields similar to those analyzed in the pooledsample titration study. Twenty-two cases where the amount of either total RNA or aRNA obtained from the patients CD138+ place cells was insufficient for GeneChip hybridization were identified. These were hybridized using standard methods and the resulting GeneChip quality metrics were analyzed to refine the minimum RNA/aRNA thresholds necessary to generate a high quality GEP suitable for clinical use. As shown in Table 3, 12/13 specimens with $>=3 \mathrm{ng} / \mu \mathrm{L}$ of total RNA and $>=280 \mathrm{ng} /$ $\mu \mathrm{L}$ aRNA resulted in successful hybridizations, defined as zero failed chip metrics and no more than three warning metrics). Below these thresholds a drop in hybridization quality was observed, indicating the GEP from such cases may be unreliable for clinical use.

Consequently a threshold of $>=3 \mathrm{ng} / \mu \mathrm{L}$ of total RNA and $>=280 \mathrm{ng} / \mu \mathrm{L}$ aRNA was set for routine MyPRS testing. This amount of total RNA can be isolated from approximately 20,000 CD138+ plasma cells. After GeneChip hybridization, each profile must pass the ResultsPX GeneChip QC model before being used to calculate a patient's GEP70 risk score, ensuring result integrity.

\section{Personalized gene expression heat-map assists in interpreting a patient's GEP70 score in the context of patients with known outcomes}

For each $\mathrm{MyPRS}^{\oplus}$ specimen analyzed, the 70 gene expression values used to compute the patients risk score are combined with a matrix of 70-gene data from 559 patients used to originally train and validate the prognostic algorithm [9] (data available at NCBI GEO ID: GSE2658). 


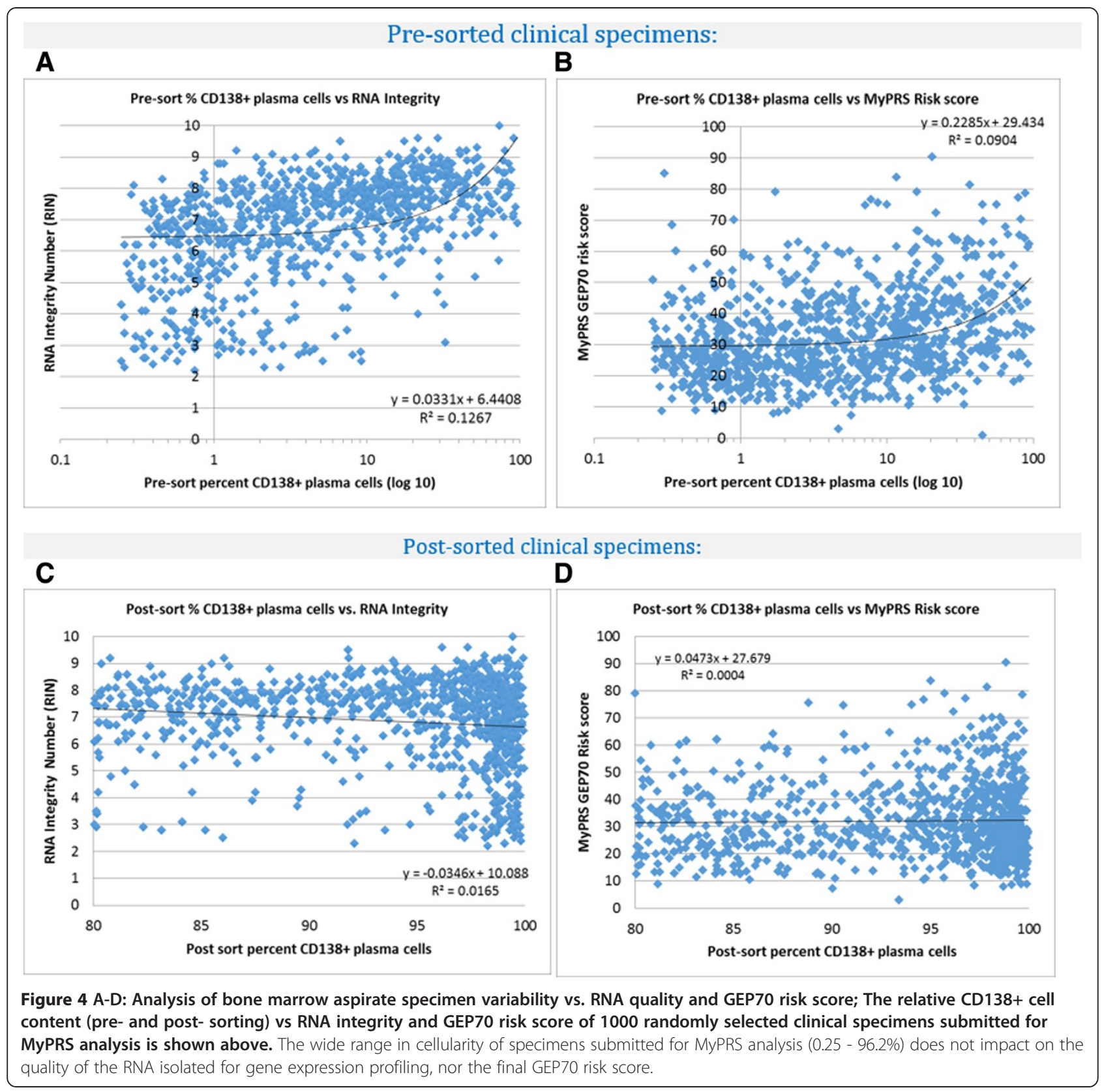

These gene expression profiles were generated from newly diagnosed patients who were enrolled in Total Therapy 2 (Thalidomide/Dexamethasone or Dex + high dose melphalan (Mel) supported autologous stem cell transplantation (ASCT)) or 3 (TT2; TT3; bortezomib-thalidomide-dexamethasone + Mel-ASCT) at UAMS prior to the commencement of their treatment.

In order to visualize the relationship between direction of differential gene expression and risk of relapse, hierarchical clustering is used to arrange the matrix rows (genes), while the columns (patients) are ordered by increasing GEP70 risk score. The published relapse-freesurvival (RFS) times for patients in this trial are used to label each patient as $<5$ yrs RFS (blue) or $>5$ yrs RFS (red), allowing the physician to interpret the gene expression patterns in context with the end point of interest.

As the example shown in Figure 5 illustrates, the GEP profile of the test patient is highlighted (yellow line), allowing the physician to visually compare the expression of the 70 prognostic genes in their patient compared to a large number of other multiple myeloma patients with known outcomes.

\section{Discussion}

The UAMS 70-gene expression profile has been established as a powerful predictor of disease outcome in 
Table 2 GeneChip QC metric summary and GEP70 scores for pooled aRNA titration experiments

\begin{tabular}{|c|c|c|c|c|c|c|}
\hline $\begin{array}{l}\text { Titration study } \\
\text { Experiment } 1 \text { Chip ID }\end{array}$ & $\begin{array}{l}\mu \mathrm{g} \text { aRNA hybridized } \\
\text { to chip }\end{array}$ & $\begin{array}{l}\text { GEP70 risk } \\
\text { group }\end{array}$ & $\begin{array}{l}\text { GEP70 risk } \\
\text { score }\end{array}$ & $\begin{array}{l}\text { Mean } \\
\text { GEP70 }\end{array}$ & $\begin{array}{l}\text { Standard } \\
\text { deviation }\end{array}$ & $\begin{array}{c}\text { Chip QC Metrics Fail/ } \\
\text { Warning/Pass }\end{array}$ \\
\hline RE13-000031-850291.CEL & 10 & Low & 41.11 & 41.73 & 0.56 & $0 / 0 / 7$ \\
\hline RE13-000032-850251.CEL & 10 & Low & 42.19 & & & $0 / 0 / 7$ \\
\hline RE13-000033-850371.CEL & 10 & Low & 41.88 & & & $0 / 0 / 7$ \\
\hline RE13-000034-850240.CEL & 8 & Low & 41.20 & 41.25 & 0.29 & $0 / 0 / 7$ \\
\hline RE13-000035-850377.CEL & 8 & Low & 40.98 & & & $0 / 0 / 7$ \\
\hline RE13-000036-850294.CEL & 8 & Low & 41.55 & & & $0 / 0 / 7$ \\
\hline RE13-000037-850370.CEL & 6 & Low & 40.67 & 41.31 & 1.01 & $0 / 0 / 7$ \\
\hline RE13-000038-850379.CEL & 6 & Low & 42.47 & & & 0/0/7 \\
\hline RE13-000039-850245.CEL & 6 & Low & 40.78 & & & 0/0/7 \\
\hline RE13-000040-850236.CEL & 4 & Low & 40.90 & 41.42 & 0.54 & $0 / 0 / 7$ \\
\hline RE13-000041-850376.CEL & 4 & Low & 41.38 & & & 0/0/7 \\
\hline RE13-000042-850395.CEL & 4 & Low & 41.98 & & & $0 / 0 / 7$ \\
\hline RE13-000043-850397.CEL & 2 & Low & 41.23 & 41.17 & 0.70 & $0 / 1 / 7$ \\
\hline RE13-000044-850358.CEL & 2 & Low & 41.85 & & & $0 / 0 / 7$ \\
\hline \multirow[t]{2}{*}{ RE13-000045-850369.CEL } & 2 & Low & 40.45 & & & $0 / 0 / 7$ \\
\hline & & & Mean: & 41.37 & 0.62 & \\
\hline $\begin{array}{l}\text { Titration study } \\
\text { experiment } 2 \text { Chip ID }\end{array}$ & $\begin{array}{l}\mu \mathrm{g} \text { aRNA } \\
\text { hybridized }\end{array}$ & $\begin{array}{l}\text { GEP70 risk } \\
\text { group }\end{array}$ & $\begin{array}{l}\text { GEP70 risk } \\
\text { score }\end{array}$ & $\begin{array}{l}\text { Mean } \\
\text { GEP70 }\end{array}$ & $\begin{array}{l}\text { Standard } \\
\text { deviation }\end{array}$ & $\begin{array}{c}\text { Chip QC Metrics Fail/ } \\
\text { Warning/Pass }\end{array}$ \\
\hline RE13-000046-840059.CEL & 10 & Low & 43.48 & 41.65 & 1.88 & $0 / 0 / 7$ \\
\hline RE13-000047-840224.CEL & 10 & Low & 41.76 & & & $0 / 0 / 7$ \\
\hline RE13-000048-840239.CEL & 10 & Low & 39.72 & & & 0/0/7 \\
\hline RE13-000049-840201.CEL & 8 & Low & 43.95 & 43.46 & 0.43 & $0 / 0 / 7$ \\
\hline RE13-000050-840219.CEL & 8 & Low & 43.22 & & & $0 / 0 / 7$ \\
\hline RE13-000051-840245.CEL & 8 & Low & 43.20 & & & 0/0/7 \\
\hline RE13-000052-840243.CEL & 6 & Low & 43.97 & 41.88 & 1.92 & $0 / 0 / 7$ \\
\hline RE13-000053-840205.CEL & 6 & Low & 40.19 & & & $0 / 0 / 7$ \\
\hline RE13-000054-840242.CEL & 6 & Low & 41.50 & & & $0 / 0 / 7$ \\
\hline RE13-000055-840246.CEL & 4 & Low & 42.71 & 43.20 & 0.96 & $0 / 0 / 7$ \\
\hline RE13-000056-840051.CEL & 4 & Low & 44.31 & & & $0 / 1 / 6$ \\
\hline RE13-000057-840199.CEL & 4 & Low & 42.59 & & & 0/0/7 \\
\hline RE13-000058-840213.CEL & 2 & Low & 43.01 & 42.81 & 0.69 & $0 / 1 / 6$ \\
\hline RE13-000059-840032.CEL & 2 & Low & 42.04 & & & $0 / 1 / 6$ \\
\hline \multirow[t]{2}{*}{ RE13-000060-840236.CEL } & 2 & Low & 43.37 & & & $0 / 1 / 6$ \\
\hline & & & Mean: & 42.60 & 1.18 & \\
\hline
\end{tabular}

newly diagnosed and relapsed multiple myeloma patients. To enable use of this GEP algorithm in a high throughput clinical setting, a direct comparison of GEP70 scores generated in two laboratories was performed and minimum specimen requirements and quality control metrics were devised in order to ensure reliable, high quality prognostic results.

Outcome prediction was found to be highly similar for specimens analyzed in either the UAMS or Signal Genetics' CLIA-certified laboratories. Importantly, a small number of cases in this study had discordant risk group predictions between the laboratories. These were cases where the risk score was very close to the classification threshold (45.2), indicating that care should be exercised when interpreting the risk score when it is close to this value. The number of cases at the threshold is exceedingly small as indicated by the bi-modal distribution of risk scores [6]. Further validation work was subsequently carried out to determine an appropriate confidence interval for the risk score, based on the observed technical noise present in the system. 
Table 3 Low RNA-yield clinical specimens: Nanodrop RNA 260/280 ratio, aRNA concentration and GeneChip QC metrics

\begin{tabular}{|c|c|c|c|c|c|c|}
\hline Case number & Specimen type & $\begin{array}{l}\text { Post-sort no. of } \\
\text { CD138+ cells }\end{array}$ & $\begin{array}{l}\text { RNA conc. } \\
\text { (ng/ } \mu \mathrm{L})\end{array}$ & $\begin{array}{c}\text { aRNA conc. } \\
\text { (ng/ } / \mu \mathrm{L})\end{array}$ & $\begin{array}{c}\text { Chip QC Metrics } \\
\text { (Fail, Warning, Pass) }\end{array}$ & $\begin{array}{l}\text { Pass/Fail } \\
\text { Chip QC }\end{array}$ \\
\hline RE13-000082 & Archival samples with low yield & 36,000 & 11.0 & 1506.1 & $0,1,6$ & Pass \\
\hline RE13-000079 & Archival samples with low yield & 32,000 & 5.3 & 708.6 & $0,1,6$ & Pass \\
\hline RE13-000080 & Archival samples with low yield & $1,896,000$ & 6.4 & 689.7 & $0,1,6$ & Pass \\
\hline RE13-000076 & Archival samples with low yield & 40,000 & 3.1 & 545.1 & $0,1,6$ & Pass \\
\hline RE13-000092 & Fresh sample with low yield & 22,000 & 10.4 & 533 & $0,0,7$ & Pass \\
\hline RE13-000074 & Archival samples with low yield & 80,000 & 10.8 & 455.7 & $0,1,6$ & Pass \\
\hline RE13-000063 & Archival samples with low yield & 76,000 & 8.1 & 426.4 & $0,0,7$ & Pass \\
\hline RE13-000077 & Archival samples with low yield & 90,000 & 6.1 & 410.1 & $0,1,6$ & Pass \\
\hline RE13-000089 & Fresh sample with low yield & 32,000 & 9.1 & 383.3 & $0,0,7$ & Pass \\
\hline RE13-000064 & Archival samples with low yield & 180,000 & 5.5 & 339.9 & $0,1,6$ & Pass \\
\hline RE13-000073 & Archival samples with low yield & 43,000 & 10.4 & 311.1 & $0,0,7$ & Pass \\
\hline RE13-000075 & Archival samples with low yield & 80,000 & 2.4 & 304 & $0,1,6$ & Pass \\
\hline RE13-000066 & Archival samples with low yield & 18,000 & 6.9 & 290.4 & $0,1,6$ & Pass \\
\hline RE13-000085 & Fresh sample with low yield & 23,000 & 13.3 & 286 & $0,1,6$ & Pass \\
\hline RE13-000069 & Archival samples with low yield & 24,000 & 8.3 & 281.1 & $0,1,6$ & Pass \\
\hline RE13-000088 & Fresh sample with low yield & 20,000 & 9.6 & 227.8 & $0,1,6$ & Pass \\
\hline RE13-000081 & Archival samples with low yield & 692,000 & 8.2 & 361.7 & $3,2,2$ & Fail \\
\hline RE13-000084 & Fresh sample with low yield & 36,000 & 5.8 & 341.6 & $1,0,6$ & Fail \\
\hline RE13-000067 & Archival samples with low yield & 188,000 & 6.2 & 271.2 & $0,3,4$ & Fail \\
\hline RE13-000068 & Archival samples with low yield & 470,000 & 7.7 & 263.3 & $2,1,4$ & Fail \\
\hline RE13-000071 & Archival samples with low yield & 20,000 & 7.7 & 254.6 & $0,3,4$ & Fail \\
\hline RE13-000061 & Archival samples with low yield & 60,000 & 3.1 & 220 & $0,3,4$ & Fail \\
\hline RE13-000083 & Archival samples with low yield & 192,000 & 5.4 & 215.5 & $2,4,1$ & Fail \\
\hline RE13-000078 & Archival samples with low yield & 17,000 & 3.4 & 214.6 & $1,2,4$ & Fail \\
\hline RE13-000065 & Archival samples with low yield & 36,000 & 5.5 & 208.4 & $1,2,4$ & Fail \\
\hline RE13-000090 & Fresh sample with low yield & 18,000 & 4.8 & 166.6 & $0,3,4$ & Fail \\
\hline RE13-000091 & Fresh sample with low yield & 9,000 & 6.2 & 144.7 & $0,3,4$ & Fail \\
\hline RE13-000062 & Archival samples with low yield & 10,000 & 2.4 & 122.8 & $2,3,2$ & Fail \\
\hline RE13-000070 & Archival samples with low yield & 30,000 & 2.5 & 100.5 & $3,2,2$ & Fail \\
\hline RE13-000086 & Fresh sample with low yield & 5,000 & 0.9 & 94.5 & $1,5,1$ & Fail \\
\hline
\end{tabular}

Values in bold type correspond to those passing the minimum acceptance threshold. Hybridization success is predicted using post-sort number of cells $(>20,000)$ RNA concenctration $(>=3 \mathrm{ng} / \mathrm{\mu L}$ ) and aRNA concentration $(>=280 \mathrm{ng} / \mu \mathrm{L})$.

The prognostic test was found to be highly stable over time as evidenced by the GEP70 scores from the MM cell line H929 control sample over a period of 12 months (Figure 2a). The 3\% CV observed in these data over a twelve month period is similar to other microarraybased prognostic assays such as MammaPrint ${ }^{\circ}$ (Agendia, CA.), a microarray based prognostic assay for breast cancer [27]. Analysis of more recent control sample data (late 2013- early 2014) shows further improvements to the assays consistency over time; CV 1.9\% (Figure 2b). As a final and important observation from these control samples, no gradual shift in the risk score over time is detected, highlighting the long-term stability of the test.
Although the technical accuracy of $\mathrm{MyPRS}^{\circ}$ is extremely high, samples close to the threshold have a higher chance of misclassification than samples further away from the threshold. However, the strong bi-modal distribution of scores proves that such cases are extremely rare. In principle, the chance of a patient with a poor clinical outcome incorrectly being assigned to a good prognosis profile should be minimized. Based on the known variation in the GEP70 risk profile, a small proportion of samples with indices close to the prediction threshold may be misclassified. For results that are close to the classification threshold of 45.2, it is recommended to evaluate the result in the context of the 


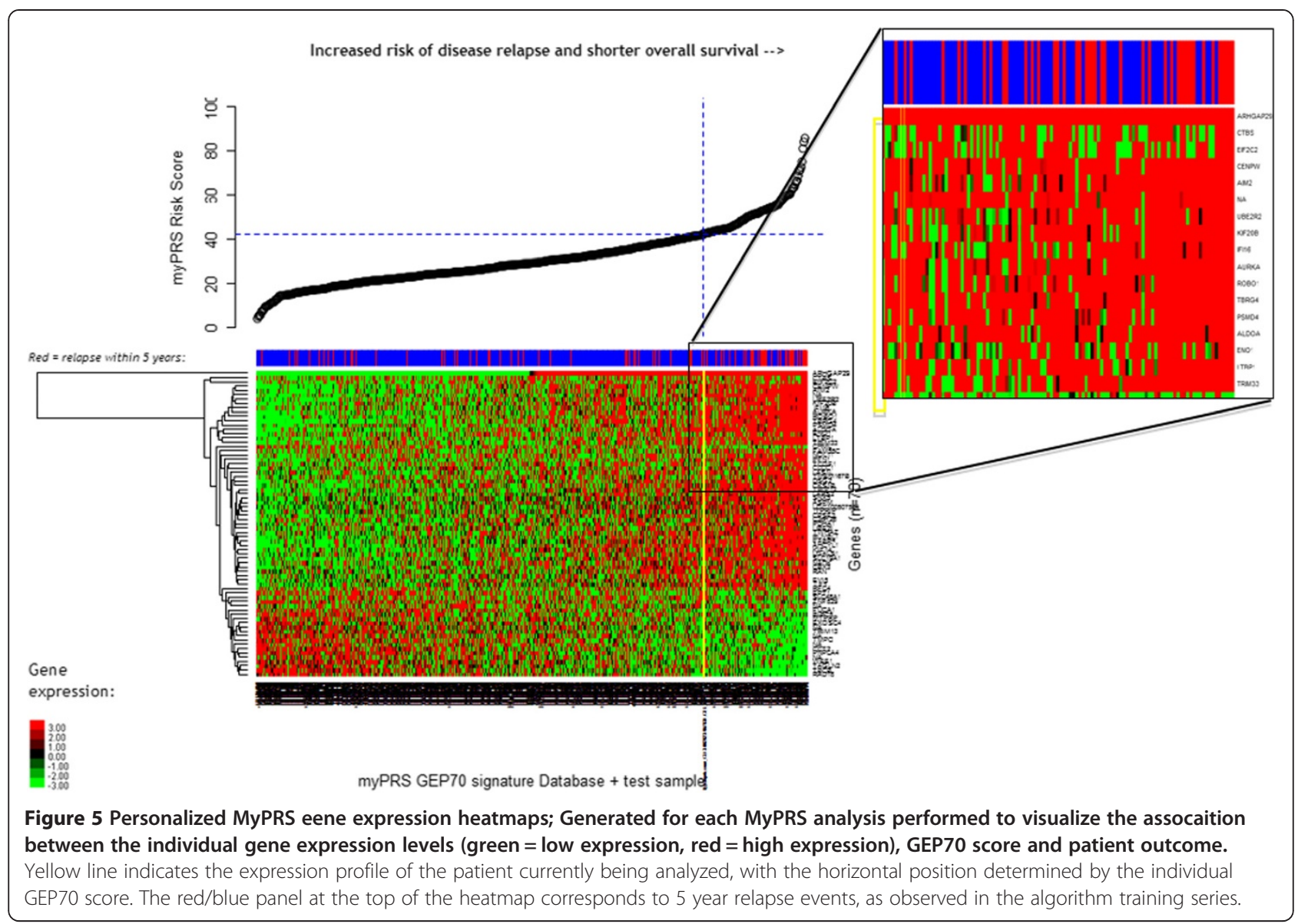

prognostic information present in the additional genomic signatures included in the MyPRS ${ }^{\bullet}$ assay; i.e. Molecular Subtype and Virtual Karyotype [9,28]. Additionally, a second sample from a separate anatomical site might be warranted. The implementation and validation of these additional signatures will be described in a separate publication.

By performing titration studies and analysis of low cellularity clinical specimens with RNA yields below manufacturer recommendations, we have determined that the Affymetrix GeneChip platform is able to generate high quality, reproducible gene expression profiles with RNA that can be isolated from as little as 20,000 CD138+ plasma cells in this context, even though the RNA yield is lower than the amount previously considered necessary. Multiple comparisons have shown the $\mathrm{MyPRS}^{\bullet}$ test is robust to the natural variation in clinical specimens submitted for analysis.

\section{Conclusion}

GEP70 has been repeatedly demonstrated to be a statistically superior, standardized method of personalized multiple myeloma prognosis and molecular characterization, with less subjectivity than conventional methods such as
FISH and cytogenetics. Even as the expression or mutational status of single genes are shown to influence response to specific myeloma treatments, e.g. expression levels of the glucocorticoid receptor gene NR3C1 and thalidomide [29], 'treatment-independent' risk-stratification assays such as GEP70 are likely to remain an important component in providing tailored treatment plans and ensuring optional outcomes.

The reproducibility of the $\mathrm{MyPRS}^{\circ}$ test and the similarity of its results to those obtained from specimens analyzed in academic research laboratories demonstrate that it is an excellent tool to predict outcome of disease in MM patients. Standardization of specimen processing and the establishment of a comprehensive quality control program make the GEP70 assay highly suitable for the routine diagnostic clinical setting. Despite the wide variation in bone marrow aspirate specimen cellularity, we describe a series of novel quality control measurements that reliably produce high quality gene expression data, suitable for clinical use.

The MyPRS test is a stable, objective and standardized method for predicting prognosis in patients with multiple myeloma, supported by extensive clinical and technical validation data. 


\section{Competing interests}

RVL, RF, NB, JR, SR, and JDS are employees of Signal Genetics. BB and JDS hold patents on the use of gene expression profiling for multiple myeloma. RVL, SR and JDS own stock in Signal Genetics.

\section{Authors' contributions}

$R F, N B$, JR performed the specimen processing and gene expression profiling. RVL analyzed the quality control data and coordinated the drafting of the manuscript. SR, CH, BB and JDS were involved in drafting the manuscript, study design and coordination. All authors read and approved the manuscript.

\section{Acknowledgements}

The authors wish to acknowledge Dr William Bellamy and Dr John Theus for their assistance in developing the MyPRS assay. Thank-you to Dr John Crowley and the Cancer Research and Biostatistics (CRAB) team for assistance in clinical data management and statistical analysis and to Sarah Starnes and Mace Moore for their involvement in validation experiments. We would also like to thank Ya-Wei Qiang for providing the cell line material for control sample use.

\section{Author details}

${ }^{1}$ Signal Genetics, 667 Madison Avenue, 14th Floor, New York, NY 10065, USA. ${ }^{2}$ University of Arkansas for Medical Sciences, Myeloma Institute for Research and Treatment, 4301 West Markham, Slot 816, Little Rock, AR 72205, USA.

Received: 7 March 2014 Accepted: 7 May 2014

Published: 17 May 2014

\section{References}

1. Veer $L, v$ 't Dai $H$, van de Vijver MJ, He YD, Hart AA, Mao M, Peterse HL, van der Kooy K, Marton MJ, Witteveen AT, Schreiber GJ, Kerkhoven RM, Roberts C, Linsley PS, Bemards R, Friend SH: Gene expression profiling predicts clinical outcome of breast cancer. Nature 2002, 415(6871):530-536.

2. Van Laar RK: An online gene expression assay for determining adjuvant therapy eligibility in patients with stage 2 or 3 colon cancer. $\mathrm{Br} J$ Cancer 2010, 103(12):1852-1857.

3. Bittner M, Meltzer $P$, Chen $Y$, Jiang $Y$, Seftor E, Hendrix M, Radmacher M, Simon R, Yakhini Z, Ben-Dor A, Sampas N, Dougherty E, Wang E, Marincola F, Gooden C, Lueders J, Glatfelter A, Pollock P, Carpten J, Gillanders E, Leja D, Dietrich K, Beaudry C, Berens M, Alberts D, Sondak V: Molecular classification of cutaneous malignant melanoma by gene expression profiling. Nature 2000, 406(6795):536-540.

4. Roepman P, Jassem J, Smit EF, Muley T, Niklinski J, van de Velde T, Witteveen AT, Rzyman W, Floore A, Burgers S, Giaccone G, Meister M, Dienemann H, Skrzypski M, Kozlowski M, Mooi WJ, van Zandwijk N: An immune response enriched 72-gene prognostic profile for early-stage non-small-cell lung cancer. Clin Cancer Res 2009, 15(1):284-290.

5. Perou C, Sorlie T, Eisen M, van de Rijn M, Jeffrey S, Rees C, Pollack J, Ross D, Johnsen H, Akslen L: Molecular portraits of human breast tumours. Nature 2000, 406(6797):747-752.

6. Shaughnessy JD, Zhan F, Burington BE, Huang Y, Colla S, Hanamura I, Stewart JP, Kordsmeier B, Randolph C, Williams DR, Xiao Y, Xu H, Epstein J, Anaissie E, Krishna SG, Cottler-Fox M, Hollmig K, Mohiuddin A, Pineda-Roman M, Tricot G, van Rhee F, Sawyer J, Alsayed Y, Walker R, Zangari M, Crowley J. Barlogie B: A validated gene expression model of high-risk multiple myeloma is defined by deregulated expression of genes mapping to chromosome 1. Blood 2007, 109(6):2276-2284.

7. Nair B, Shaughnessy JD, Zhou Y, Astrid-Cartron M, Qu P, van Rhee F, Anaissie E, Alsayed Y, Waheed S, Hollmig K, Szymonifka J, Petty N, Hoering A, Barlogie B: Gene expression profiling of plasma cells at myeloma relapse from tandem transplantation trial Total Therapy 2 predicts subsequent survival. Blood 2009, 113(26):6572-6575.

8. Shaughnessy JD, Barlogie B: Using genomics to identify high-risk myeloma after autologous stem cell transplantation. Biol Blood Marrow Transplant 2006, 12(1):77-80.

9. Zhan F, Huang Y, Colla S, Stewart JP, Hanamura I, Gupta S, Epstein J, Yaccoby S, Sawyer J, Burington B, Anaissie E, Hollmig K, Pineda-Roman M, Tricot G, van Rhee F, Walker R, Zangari M, Crowley J, Barlogie B, Shaughnessy JD: The molecular classification of multiple myeloma. Blood 2006, 108(6):2020-2028.
10. Shaughnessy JD, Haessler J, Van Rhee F, Anaissie E, Pineda-Roman M, Cottler-Fox M, Hollmig K, Zangari M, Mohiuddin A, Alsayed Y, Grazziutti M, Epstein J, Crowley J, Barlogie B: Testing standard and genetic parameters in 220 patients with multiple myeloma with complete data sets: superiority of molecular genetics. Br J Haematol 2007, 137(6):530-536.

11. Barlogie B, Anaissie E, Van Rhee F, Haessler J, Hollmig K, Pineda-Roman M, Cottler-Fox M, Mohiuddin A, Alsayed Y, Tricot G, Bolejack V, Zangari M, Epstein J, Petty N, Steward D, Jenkins B, Gurley J, Sullivan E, Crowley J, Shaughnessy JD: Incorporating bortezomib into upfront treatment for multiple myeloma: early results of total therapy 3. Br J Haematol 2007 , 138(2):176-185.

12. Chng WJ, Kuehl WM, Bergsagel PL, Fonseca R: Translocation $t(4 ; 14)$ retains prognostic significance even in the setting of high-risk molecular signature. Leukemia 2007, 22(2):459-461.

13. Haessler J, Shaughnessy JD, Zhan F, Crowley J, Epstein J, van Rhee F, Anaissie E, Pineda-Roman M, Zangari M, Hollmig K, Mohiuddin A, Alsayed Y, Hoering A, Tricot G, Barlogie B: Benefit of complete response in multiple myeloma limited to high-risk subgroup identified by gene expression profiling. Clin Cancer Res 2007, 13(23):7073-7079.

14. Zhan F, Barlogie B, Mulligan G, Shaughnessy JD, Bryant B: High-risk myeloma: a gene expression-based risk-stratification model for newly diagnosed multiple myeloma treated with high-dose therapy is predictive of outcome in relapsed disease treated with single-agent bortezomib or high-dose dexamethasone. Blood 2008, 111(2):968-969.

15. Decaux $O$, Lodé $L$, Magrangeas $F$, Charbonnel $C$, Gouraud $W$, Jézéquel $P$, Attal M, Harousseau J-L, Moreau P, Bataille R, Campion L, Avet-Loiseau H, Minvielle $S$ : Prediction of survival in multiple myeloma based on gene expression profiles reveals cell cycle and chromosomal instability signatures in high-risk patients and hyperdiploid signatures in Low-risk patients: a study of the intergroupe francophone du myélome. J Clin Oncol 2008, 26(29):4798-4805.

16. Zhou $Y$, Nair B, Shaughnessy JD Jr, Cartron M-A, Haessler J, Anaissie E, Van Rhee F, Crowley J, Barlogie B: Cytogenetic abnormalities in multiple myeloma: poor prognosis linked to concomitant detection in random and focal lesion bone marrow samples and associated with high-risk gene expression profile. Br J Haematol 2009, 145(5):637-641.

17. Dickens NJ, Walker BA, Leone PE, Johnson DC, Brito JL, Zeisig A, Jenner MW, Boyd KD, Gonzalez D, Gregory WM, Ross FM, Davies FE, Morgan GJ: Homozygous deletion mapping in myeloma samples identifies genes and an expression signature relevant to pathogenesis and outcome. Clin Cancer Res 2010, 16(6):1856-1864.

18. Zhou Y, Chen L, Barlogie B, Stephens O, Wu X, Williams DR, Cartron M-A van Rhee F, Nair B, Waheed S, Pineda-Roman M, Alsayed Y, Anaissie E, Shaughnessy JD: High-risk myeloma is associated with global elevation of miRNAs and overexpression of ElF2C2/AGO2. Proc Natl Acad Sci 2010, 107(17):7904-7909.

19. Hose D, Rème T, Hielscher T, Moreaux J, Messner T, Seckinger A, Benner A, Shaughnessy JD, Barlogie B, Zhou Y, Hillengass J, Bertsch U, Neben K, Möhler T, Rossi JF, Jauch A, Klein B, Goldschmidt H: Proliferation is a central independent prognostic factor and target for personalized and risk-adapted treatment in multiple myeloma. Haematologica 2011, 96(1):87-95.

20. van Rhee F, Szymonifka J, Anaissie E, Nair B, Waheed S, Alsayed Y, Petty N, Shaughnessy JD, Hoering A, Crowley J, Barlogie B: Total Therapy 3 for multiple myeloma: prognostic implications of cumulative dosing and premature discontinuation of VTD maintenance components, bortezomib, thalidomide, and dexamethasone, relevant to all phases of therapy. Blood 2010, 116(8):1220-1227.

21. Broyl A, Hose D, Lokhorst $H$, de Knegt $Y$, Peeters J, Jauch A, Bertsch U, Buijs A, Stevens-Kroef M, Beverloo HB, Vellenga E, Zweegman S, Kersten M-J, van der Holt B, el Jarari L, Mulligan G, Goldschmidt H, van Duin M, Sonneveld P: Gene expression profiling for molecular classification of multiple myeloma in newly diagnosed patients. Blood 2010, 116(14):2543-2553.

22. Kumar SK, Uno H, Jacobus SJ, Wier SAV, Ahmann GJ, Henderson KJ, Callander NS, Haug JL, Siegel DS, Greipp PR, Fonseca R, Rajkumar SV: Impact of gene expression profiling-based risk stratification in patients with myeloma receiving initial therapy with lenalidomide and dexamethasone. Blood 2011, 118(16):4359-4362.

23. Zhan F, Hardin J, Kordsmeier B, Bumm K, Zheng M, Tian E, Sanderson R, Yang Y, Wilson C, Zangari M, Anaissie E, Morris C, Muwalla F, van Rhee F, Fassas A, Crowley J, Tricot G, Barlogie B, Shaughnessy J: Global gene expression profiling of multiple myeloma, monoclonal gammopathy of 
undetermined significance, and normal bone marrow plasma cells. Blood 2002, 99(5):1745-1757.

24. Passing $\mathrm{H}$, Bablok: A new biometrical procedure for testing the equality of measurements from two different analytical methods. Application of linear regression procedures for method comparison studies in clinical chemistry, Part I. J Clin Chem Clin Biochem 1983, 21(11):709-720.

25. R Development Core Team: $R$ : A language and environment for statistical computing. Vienna, Austria: R Foundation for Statistical Computing; 2008. ISBN 3-900051-07-0, http://www.R-project.org.

26. Gentleman RC, Carey VJ, Bates DM, Bolstad B, Dettling M, Dudoit S, Ellis B, Gautier L, Ge Y, Gentry J, Hornik K, Hothorn T, Huber W, lacus S, Irizarry R, Leisch F, Li C, Maechler M, Rossini AJ, Sawitzki G, Smith C, Smyth G, Tierney $L$, Yang JY, Zhang J: Bioconductor: open software development for computational biology and bioinformatics. Genome Biol 2004, 5(10):R80.

27. Glas AM, Floore A, Delahaye LJ, Witteveen AT, Pover RC, Bakx N, LahtiDomenici JS, Bruinsma TJ, Warmoes MO, Bernards R, Wessels LF, Van't Veer L: Converting a breast cancer microarray signature into a high-throughput diagnostic test. BMC Genomics 2006, 7:278.

28. Zhou Y, Zhang Q, Stephens O, Heuck CJ, Tian E, Sawyer JR, Cartron-Mizeracki M-A, Qu P, Keller J, Epstein J, Barlogie B, Shaughnessy JD: Prediction of cytogenetic abnormalities with gene expression profiles. Blood 2012, 119(21):e148-e150. http://bloodjournal.hematologylibrary.org/content/ 119/21/e148.

29. Heuck CJ, Szymonifka J, Hansen E, Shaughnessy JD, Usmani SZ, van Rhee F, Anaissie E, Nair B, Waheed S, Alsayed Y, Petty N, Bailey C, Epstein J, Hoering A, Crowley J, Barlogie B: Thalidomide in total therapy 2 overcomes inferior prognosis of myeloma with Low expression of the glucocorticoid receptor gene NR3C1. Clin Cancer Res 2012, 18(19):5499-5506.

doi:10.1186/1755-8794-7-25

Cite this article as: van Laar et al.: Translating a gene expression signature for multiple myeloma prognosis into a robust

high-throughput assay for clinical use. BMC Medical Genomics 2014 7:25.

\section{Submit your next manuscript to BioMed Central and take full advantage of:}

- Convenient online submission

- Thorough peer review

- No space constraints or color figure charges

- Immediate publication on acceptance

- Inclusion in PubMed, CAS, Scopus and Google Scholar

- Research which is freely available for redistribution 